\title{
Hematologic Autoimmune Manifestation Secondary to Coronavirus Disease 19 Infection - A Single-Center Experience
}

SanjaTrajkova*(D), Simona Stojanovska(D, NevenkaRidova (D), Svetlana Krstevska-Balkanov,AleksandraPivkova-Veljanovska (D) Lidija Cevreska, Marija Popova-Labacevska, Irina Panovska-Stavridis (iD

Department of Hematology, University Clinic for Hematology, Medical Faculty, Ss. Cyril and Methodius University, Skopje, Republic of Macedonia

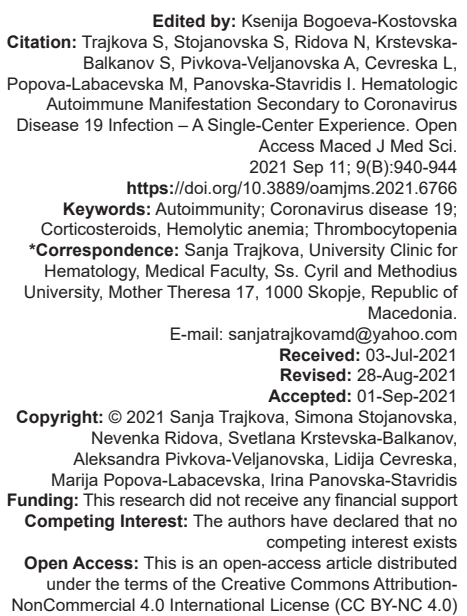

\section{Abstract}

BACKGROUND: Since December 2019, multiple human cases of novel coronavirus infection were reported representing with upper respiratory symptoms (influenza-like presentation). The virus was named the severe acute respiratory system coronavirus 2 (SARS-COV-2). Studies have reported cases of patients with coronavirus disease 19 (COVID-19) infection, including development of several autoimmune events that suggest that infection with SARS-CoV-2 may be associated with initiation of autoimmune hematological autoimmune disorders.

AIM: This study aims to review the hematological autoimmune phenomena after infection with SARS-CoV-2 to assist into the pathogenic mechanisms, clinical manifestations, and treatment of this group of patients.

MATERIALS AND METHODS: This is a retrospective study that includes 21 patients with autoimmune diseases such as secondary immune thrombocytopenia (ITP), autoimmune hemolytic anemia (AIHA), and thrombotic thrombocytopenic purpura (TTP) that have emerged after COVID-19 infection. The patients were diagnosed and treated at the University Clinic of Hematology-Skopje for a period of time from January 2020 to April 2021.

RESULTS: The most common hematologic autoimmune disorder was ITP in 13 cases (62\%) followed by AlHA in 5 cases $(24 \%)$ and TTP in 3 individuals (14\%). The mean time of onset of the hematologic autoimmune presentations was $18.4 \pm 10.3$ days. The therapy of this condition in patients with COVID-19 infection requires an individualized approach to achieve a precise balance between the risk of severe bleeding and of thromboembolic events.

CONCLUSION: Causal relationship between COVID-19 infection and these autoimmune events still requires furthe studies. We should all have in mind the risk of development of hematologic autoimmune disorders in infected patients.

\section{Introduction}

In December 2019, multiple human cases of the novel coronavirus infection were reported in Wuhan, China, in patients complaining of upper respiratory symptoms (influenza-like presentation). The virus was named severe acute respiratory system coronavirus 2 (SARS-CoV-2). Due to the high virulence rate of the newly discovered virus, various measures were taken worldwide to maintain social distance to prevent viral transmission and spread of the disease. However, despite the complete lockdown and social distancing in many countries around the world, a pandemic was declared by the World Health Organization (WHO) on March 11, 2020.

While SARS-CoV-2 mainly targets respiratory tract, resulting in respiratory failure and acute respiratory distress syndrome as the leading cause of death in diseased patients, clinical manifestations in different organs are very common. Common symptoms of SARSCoV-2 infection (coronavirus disease 19 [COVID-19]) are fever, dry cough, fatigue, sore throat, malaise, and myalgia. Symptoms such as headache, dizziness, diarrhea, nausea, and vomiting are less frequent. While the majority of patients have only mild symptoms without progression to pneumonia or mild pneumonia, $14 \%$ of patients present with severe pneumonia and $5 \%$ of patients develop a critical disease leading to acute respiratory distress syndrome (ARDS), cardiac injury, renal injury, or multiorgan failure. Autoimmune disorders including immune thrombocytopenia (ITP), GuillainBarré, and antiphospholipid syndrome have been described in association with SARS-CoV-2 infection. Recently, an increasing number of studies have shown that SARS-CoV-2 infection can result in altered immune system functions [1] and the vascular component of the disease is becoming more and more evident.

These changes can range from an inadequate immune response and abnormal cytokine or chemokine production to immune system hyperactivity and a dramatic increase in inflammatory parameters. These intense immune responses can lead to an autoimmune reaction and cytokine storm [2]. In addition, studies 
have reported cases of patients with COVID-19 who developed severe autoimmune events [3]. These facts suggest that SARS-CoV-2 infection may be associated with initiation of autoimmune disorders. Among these autoimmune manifestations, several hematological autoimmune disorders have also been reported and these have been shown to complicate the clinical course of the disease, determining the outcome in patients with COVID-19 [4], [5], [6], [7].

\section{Patients and Methods}

This was a retrospective study that included 21 patients with hematological autoimmune diseases: ITP, autoimmune hemolytic anemia (AIHA), and thrombocytopenic purpura (TTP) that had emerged after SARS-CoV-2 infection. The patients were diagnosed and treated at the University Clinic of HematologySkopje in the period between January 2020 and April 2021. The diagnosis of ITP, AIHA, and TTP was defined according to the national guidelines.

All the patients were diagnosed with SARSCoV-2 infection with a reverse transcriptase-polymerase chain reaction by nasopharyngeal swab. After the clinical presentation of the autoimmune hematological disease, all the patients were evaluated for clinical and laboratory variables which included sex, age, physical examination with evaluation of lymph nodes (cervical, axillary, and inguinal), measurement of liver and spleen size, blood cell counts (white blood cells, hemoglobin levels, and platelet counts), reticulocyte counts, peripheral blood smear, biochemistry analyses, haptoglobin levels, ferritin levels, direct antiglobulin test, ADAMTS 13, anti-ADAMTS 13 antibodies.

Response and complete response (CR) were defined according to standardized international criteria, for ITP: Platelet count of $>30 \times 10^{9} / /$ with at least doubling of the baseline value and platelet count of $>100 \times 10^{9} /$, respectively; for AIHA: Hemoglobin levels $>100 \mathrm{~g} / \mathrm{L}$ in absence of laboratory signs of hemolysis (normal reticulocyte counts, normal lactate dehydrogenase [LDH], and haptoglobin levels) [14]; and CR for TTP: Platelet count of $>150 \times 10^{9} /$, reticulocytes $<100 \times 10^{9} /$, $\mathrm{LDH}<300 \mathrm{U} / \mathrm{l}$, and haptoglobin $>40 \mathrm{mg} \%$ [15]. According to the European Union and national general data protection regulations, all patients were informed about the study and data collection by a written letter detailing their rights. The study was approved by the Ethics Committee of the University Clinic of Hematology in Skopje, Republic of Macedonia.

\section{Statistical analysis}

Statistical analysis was performed using the Statistical Package for the Social Sciences (SPSS) 23.0 software program (SPSS Inc., Chicago, IL, USA). Normally distributed data were expressed as mean \pm standard deviation (SD), while non-parametric data were expressed in median (interquartile range, IQR).

\section{Results}

A total of 21 patients with SARS-CoV-2 infection who developed hematologic autoimmune disorders during the course of infection were included in the analysis. Male and female patients constituted an almost equal proportion of the study cases, more precisely, nine patients were male and 12 patients were female. The study cases had a wide age range, from 18 years to 81 years with a median age of 56 and a mean age of $54 \pm 17.4$. The majority of the patients (16 cases $-76 \%$ ) had comorbidities. The most common presentation of SARS-CoV-2 infection in these cases was fever, reported in 11 (52\%) of them followed by coughing in $10(47 \%)$ and severe bronchopneumonia in 7 patients $(33 \%)$ (Table 1). The most common hematologic autoimmune disorder was ITP, seen in 13 cases $(62 \%)$ followed by AlHA in 5 cases $(24 \%)$ and thrombotic TTP in 3 individuals (14\%) (Table 1). The mean time of onset of the hematologic autoimmune presentations in relation to SARS-COv-2 infection for all categories of hematologic autoimmune disorders was $18.4+/-10.3$ days. Among all patients with ITP, $5(38.4 \%)$ patients had no apparent signs of bleeding at the time of diagnosis.

Among these patients, 19 patients recovered and their hematological indices related to the autoimmune disorders improved. Among the deceased cases, one was with ITP and the other one with TTP. In both cases, intracerebral hemorrhage was suspected. The patient with TTP died due to intracerebral hemorrhage within the first $24 \mathrm{~h}$, before the initiation of plasma exchange. The patient with ITP passed away due to his poor condition. It may be concluded that the remission rate was $95 \%$ (19 out of 20 patients) in cases in which autoimmune disorder-oriented treatment was administered.

\section{Treatment}

Among the patients with ITP, majority of patients, namely, nine patients, received monotherapy with corticosteroids (dexamethasone $1-1.5 \mathrm{mg} / \mathrm{kg} \mathrm{d}$.). One patient, refractory to steroid treatment, received intravenous immunoglobulins (IVIG) (1 $\mathrm{g} / \mathrm{kg} / \mathrm{d}$ - 2 days) and thrombopoietin receptor agonists (eltrombopag - $50 \mathrm{mg} / \mathrm{d}$ ). One patient received additional therapy with cyclosporin $(5 \mathrm{mg} / \mathrm{kg} / \mathrm{d})$ and rituximab (375 mg/m $\mathrm{m}^{2}$ IV once weekly $\left.\times 4\right)$, and splenectomy was performed due to poor response to 
Table 1: Characteristics, treatment, and outcome of the COVID-19-induced autoimmune ITP, AIHA, and TTP patients

\begin{tabular}{|c|c|c|c|c|c|c|c|}
\hline $\begin{array}{l}\text { Patient } \\
\text { initials }\end{array}$ & $\begin{array}{l}\text { Gender } \\
\text { and age }\end{array}$ & Patient's medical history & $\begin{array}{l}\text { Clinical presentation at COVID-19 } \\
\text { infection }\end{array}$ & $\begin{array}{l}\text { Hematologic } \\
\text { autoimmune } \\
\text { manifestation }\end{array}$ & $\begin{array}{l}\text { Timing of the } \\
\text { hematologic } \\
\text { presentations }\end{array}$ & Treatment & Outcome \\
\hline $\begin{array}{l}\text { Patient } 1 \\
\text { A.S. }\end{array}$ & $\begin{array}{l}\text { Male } 31 \\
\text { years old }\end{array}$ & Hepatitis B & $\begin{array}{l}\text { Cough, fever, severe } \\
\text { bronchopneumonia }\end{array}$ & ITP & 7 days & $\begin{array}{l}\text { Dexamethasone } \\
\text { (without response), IVIG, } \\
\text { thrombopoietin }\end{array}$ & $\begin{array}{l}\text { Recovered (response to } \\
\text { thrombopoietin) }\end{array}$ \\
\hline $\begin{array}{l}\text { Patient } 2 \\
\text { A.G. }\end{array}$ & $\begin{array}{l}\text { Male } 38 \\
\text { years old }\end{array}$ & l & Severe bronchopneumonia & ITP & 5 days & Dexamethasone & $\begin{array}{l}\text { Recovered (response to } \\
\text { dexamethasone) }\end{array}$ \\
\hline $\begin{array}{l}\text { Patient } 3 \\
\text { S.V. }\end{array}$ & $\begin{array}{l}\text { Female } 29 \\
\text { years old }\end{array}$ & $\begin{array}{l}\text { Hepatitis B Hashimoto } \\
\text { thyroiditis }\end{array}$ & $\begin{array}{l}\text { Asymptomatic COVID } 19 \text { infection, } \\
\text { petechial hemorrhage and bruising }\end{array}$ & ITP & 20 days & $\begin{array}{l}\text { Dexamethasone, (without } \\
\text { response), splenectomy, } \\
\text { cyclosporine, rituximab }\end{array}$ & $\begin{array}{l}\text { Recovered (response to } \\
\text { cyclosporine and rituximab) }\end{array}$ \\
\hline $\begin{array}{l}\text { Patient } 4 \\
\text { D.S. }\end{array}$ & $\begin{array}{l}\text { Female } 56 \\
\text { years old }\end{array}$ & $\begin{array}{l}\text { Type } 2 \text { diabetes } \\
\text { hypertension obesity } \\
\text { cardiomyopathy }\end{array}$ & $\begin{array}{l}\text { Fever, cough, headache, fatigue, } \\
\text { petechial hemorrhage }\end{array}$ & ITP & 10 days & $\begin{array}{l}\text { Dexamethasone, } \\
\text { cyclosporine }\end{array}$ & $\begin{array}{l}\text { Recovered (response to } \\
\text { cyclosporine) }\end{array}$ \\
\hline $\begin{array}{l}\text { Patient } 5 \\
\text { P.B. }\end{array}$ & $\begin{array}{l}\text { Male } 71 \\
\text { years old }\end{array}$ & $\begin{array}{l}\text { Chronic obstructive } \\
\text { pulmonary disease, benign } \\
\text { prostatic hyperplasia }\end{array}$ & Severe bronchopneumonia & ITP & 20 days & $\begin{array}{l}\text { Dexamethasone, } \\
\text { cyclosporine }\end{array}$ & $\begin{array}{l}\text { Recovered (response } \\
\text { to dexamethasone and } \\
\text { cyclosporine) }\end{array}$ \\
\hline $\begin{array}{l}\text { Patient } 6 \\
\text { D.N. }\end{array}$ & $\begin{array}{l}\text { Female } 67 \\
\text { years old }\end{array}$ & Hypertension & $\begin{array}{l}\text { Asymptomatic COVID19 infection, } \\
\text { petechial hemorrhage and bruising }\end{array}$ & ITP & 30 days & Dexamethasone & $\begin{array}{l}\text { Recovered (response to } \\
\text { dexamethasone) }\end{array}$ \\
\hline $\begin{array}{l}\text { Patient } 7 \\
\text { O.S. }\end{array}$ & $\begin{array}{l}\text { Male } 37 \\
\text { years old }\end{array}$ & l & $\begin{array}{l}\text { Bronchopneumonia, fever, fatigue, } \\
\text { petechial hemorrhage }\end{array}$ & ITP & 20 days & Dexamethasone & $\begin{array}{l}\text { Recovered (response to } \\
\text { dexamethasone) }\end{array}$ \\
\hline $\begin{array}{l}\text { Patient } 8 \\
\text { D.N. }\end{array}$ & $\begin{array}{l}\text { Female } 71 \\
\text { years old }\end{array}$ & $\begin{array}{l}\text { Breast cancer, bipolar } \\
\text { disorder }\end{array}$ & Asymptomatic COVID-19 infection & ITP & 30 days & Dexamethasone & $\begin{array}{l}\text { Recovered (response to } \\
\text { dexamethasone) }\end{array}$ \\
\hline $\begin{array}{l}\text { Patient } 9 \\
\text { D.A. }\end{array}$ & $\begin{array}{l}\text { Female } 73 \\
\text { years old }\end{array}$ & $\begin{array}{l}\text { Hypertension, Type } 2 \\
\text { diabetes }\end{array}$ & $\begin{array}{l}\text { Asymptomatic COVID-19, petechial } \\
\text { hemorrhage, and bruising }\end{array}$ & ITP & 30 days & Dexamethasone & $\begin{array}{l}\text { Recovered (response to } \\
\text { dexamethasone) }\end{array}$ \\
\hline $\begin{array}{l}\text { Patient } 10 \\
\text { K.S. }\end{array}$ & $\begin{array}{l}\text { Female } 18 \\
\text { years old }\end{array}$ & 1 & $\begin{array}{l}\text { Asymptomatic COVID-19 infection, } \\
\text { petechial hemorrhage, and bruising }\end{array}$ & ITP & 20 days & Dexamethasone & Recovered \\
\hline $\begin{array}{l}\text { Patient } 11 \\
\text { Lj. S. }\end{array}$ & $\begin{array}{l}\text { Female } 62 \\
\text { years old }\end{array}$ & I & $\begin{array}{l}\text { Asymptomatic COVID-19 infection, } \\
\text { petechial hemorrhage, and bruising }\end{array}$ & ITP & 20 days & Dexamethasone & Recovered \\
\hline $\begin{array}{l}\text { Patient } 12 \\
\text { V.P. }\end{array}$ & $\begin{array}{l}\text { Male } 68 \\
\text { years old }\end{array}$ & l & $\begin{array}{l}\text { Severe bronchopneumonia, fever } \\
\text { bruising }\end{array}$ & ITP & 10 days & Dexamethasone & Recovered \\
\hline $\begin{array}{l}\text { Patient } 13 \\
\text { PM }\end{array}$ & $\begin{array}{l}\text { Male } 81 \\
\text { years old }\end{array}$ & Hypertension & $\begin{array}{l}\text { Fever, headache, dizziness, } \\
\text { neurological manifestations }\end{array}$ & ITP & 10 days & Dexamethasone & The lethal outcome \\
\hline $\begin{array}{l}\text { Patient } 14 \\
\text { M.A. }\end{array}$ & $\begin{array}{l}\text { Male } 38 \\
\text { years old }\end{array}$ & Hypertension & Fever, cough, headache, fatigue & AlHA & 30 days & Dexamethasone & Recovered \\
\hline $\begin{array}{l}\text { Patient } 15 \\
\text { M.B. }\end{array}$ & $\begin{array}{l}\text { Male } 52 \\
\text { years old }\end{array}$ & $\begin{array}{l}\text { Hypertension, Type } 2 \\
\text { diabetes, obesity }\end{array}$ & $\begin{array}{l}\text { Severe bronchopneumonia, fever, } \\
\text { cough, headache, fatigue }\end{array}$ & AlHA & 30 days & $\begin{array}{l}\text { Dexamethasone, } \\
\text { cyclosporine }\end{array}$ & $\begin{array}{l}\text { Recovered (response to } \\
\text { cyclosporine) }\end{array}$ \\
\hline $\begin{array}{l}\text { Patient } 16 \\
\text { E.R. }\end{array}$ & $\begin{array}{l}\text { Female } 78 \\
\text { years old }\end{array}$ & $\begin{array}{l}\text { Painful polyneuropathy, } \\
\text { radiculopathy, } \\
\text { hypertension }\end{array}$ & Asymptomatic COVID-19 infection & AlHA & $\begin{array}{l}\text { At the time } \\
\text { of COVID-19 } \\
\text { testing }\end{array}$ & Dexamethasone & Recovered \\
\hline $\begin{array}{l}\text { Patient } 17 \\
\text { S.P. }\end{array}$ & $\begin{array}{l}\text { Female } 43 \\
\text { years old }\end{array}$ & $\begin{array}{l}\text { Chronic obstructive } \\
\text { pulmonary disease }\end{array}$ & $\begin{array}{l}\text { Asymptomatic COVID-19, petechial } \\
\text { hemorrhage, and bruising }\end{array}$ & AlHA & 30 days & Dexamethasone & Recovered \\
\hline $\begin{array}{l}\text { Patient } 18 \\
\text { Z.A. }\end{array}$ & $\begin{array}{l}\text { Female } 58 \\
\text { years old }\end{array}$ & $\begin{array}{l}\text { Leg ulcer (ulcus cruris), leg } \\
\text { fracture }\end{array}$ & Cough, headache, fatigue & AlHA & 15 days & $\begin{array}{l}\text { Dexamethasone, } \\
\text { azathioprine (Imuran) }\end{array}$ & Recovered \\
\hline $\begin{array}{l}\text { Patient } 19 \\
\text { M.I. }\end{array}$ & $\begin{array}{l}\text { Female } 53 \\
\text { years old }\end{array}$ & Hypertension & Asymptomatic COVID-19 infection & TTP & 14 days & $\begin{array}{l}\text { Dexamethasone, } \\
\text { plasmapheresis, } \\
\text { cyclosporine, rituximab }\end{array}$ & Recovered \\
\hline $\begin{array}{l}\text { Patient } 20 \\
\text { R.N. }\end{array}$ & $\begin{array}{l}\text { Male } 57 \\
\text { years old }\end{array}$ & $\begin{array}{l}\text { Multiple myeloma, } \\
\text { autologous stem cell } \\
\text { transplant }\end{array}$ & $\begin{array}{l}\text { Severe bronchopneumonia, fever, } \\
\text { headache, dizziness, neurological } \\
\text { manifestations }\end{array}$ & TTP & 5 days & Dexamethasone & The lethal outcome \\
\hline $\begin{array}{l}\text { Patient } 21 \\
\text { B.T. }\end{array}$ & $\begin{array}{l}\text { Female, } 55 \\
\text { years old }\end{array}$ & Hypothyroidism & Asymptomatic COVID-19 infection & TTP & 20 days & $\begin{array}{l}\text { Dexamethasone } \\
\text { (osteoporosis due } \\
\text { to corticosteroids), } \\
\text { plasmapheresis, } \\
\text { cyclosporine, rituximab }\end{array}$ & Recovered \\
\hline
\end{tabular}

ITP: Immune thrombocytopenia, AIHA: Autoimmune hemolytic anemia, TTP: Thrombocytopenic purpura, IVIG: Intravenous immunoglobulins, COVID-19: Coronavirus disease 19.

previous therapy. Two patients received therapy with corticosteroids and cyclosporine (Table 1). Among the patients treated with corticosteroids, therapeutic response was not achieved in four patients. These patients received second-line treatment with IVIG and other immunosuppressive drugs. All AlHA patients were treated with steroids or a combination of steroids and immunosuppressive drugs (Table 1). Patients with TTP were treated with plasmapheresis, corticosteroids, and immunosuppressive therapy.

\section{Discussion}

Hematologic autoimmune sequels in the patients infected with SARS-CoV-2 infection, observed in this study were ITP, AIHA, and TTP (syndrome Moskowitz). Although the exact mechanism of these immune complications is unknown, there are evidences suggesting a causal link between coronavirus infection and their occurrence.

Several viral infections such as HIV, hepatitis $\mathrm{C}$ virus, and Epstein-Barr virus have been associated with hematologic autoimmune disorders so far. Therefore, SARS-CoV-2 infection may be attributed to trigger a cascade of events, involving both the innate and adaptive immunity mechanisms, resulting in autoimmunity [8]. The number of all SARS-CoV-2infected individuals in Macedonia in the period covered in the study was approximately 131,424

In about one-third of patients with SARS-CoV-2 infection, mild-to-severe degree of thrombocytopenia is found. In this study, classic causes of thrombocytopenia, such as consumption coagulopathy, toxic shock, 
heparin-induced thrombocytopenia, and thrombotic TTP, were excluded and in all patients with autoimmune mechanisms following SARS-CoV-2 infection, a series of tests were performed to rule out the classic causes of thrombocytopenia. In all cases, the diagnosis of ITP was established in absence of any demonstrable primary disease.

The occurrence of viral induction of autoimmunity can be explained in several ways, including molecular mimicry, cryptic antigen expression, and epitope spreading. Molecular mimicry is stimulation of the immune system through certain microbial antigens that can lead to generation of cross-reactive antibodies to certain glycoproteins on platelet surface. These antiplatelet antibodies and platelets antigens form immune complexes, which result in platelets clearance by reticuloendothelial system. Viruses are capable of inducing expression of cryptic antigens through direct infection of the cells.

Management of coexisting conditions in patients with COVID-19 requires an individualized approach to achieve a precise balance between the risk of severe bleeding and thromboembolic events. Steroid treatment is the standard and most used firstline therapy for the management of newly diagnosed or relapsed ITP [9], [10]. Administration of steroid therapy increases the risk of viral infections and may lead to suppression of the immune system, but in patients with ITP who received steroids, no worsening of COVID19 course or symptoms was reported. In patients with comorbidities, minimum effective dose and duration should be considered. Another first-line therapy for ITP is IVIG, which is more appropriate in cases with very low platelet counts and in patients at increased risk of severe bleeding. A practical guidance for the management of adults with ITP during the COVID-19 pandemic by Pavord et al. [11] recommends steroids as first-line treatment at minimum effective dose and duration and IVIG in two occasions: (1) First-line option in patients at risk for severe bleeding and (2) patients who failed first-line therapy with steroids.

Another hematologic autoimmune disorder seen in our patients with COVID-19 is AIHA, which is a rare autoimmune disorder characterized by the presence of autoantibodies that react with red blood cells and result in their destruction [12]. This disorder should mainly be suspected in patients with severe anemia and an abrupt decrease in hemoglobin concentration in a case when no other attributable causes can be identified. An AlHA was suspected in our cases due to symptomatic anemia, evidence of ongoing hemolysis on the blood tests, and a history of a viral infection. Hemolysis secondary to viral infections is a common finding [13].

Although the mechanism is not fully understood, there are theories that propose an autoimmune response by molecular simulation of host antigens by viral-derived peptides that cause cross-activation of autoreactive $\mathrm{T}$ or $\mathrm{B}$ cells. The strongest hypothesis for this phenomenon relies on the inflammatory context caused by SARS-CoV-2 infection. A cytokinerich inflammatory environment alters the antigen presentation process by the antigen presenting cells witch results in a modified antigen repertoire presented to $\mathrm{T}$ lymphocytes, of which cryptic antigens may be a part. A second hypothesis is based on the existence of a shared epitope sequence between the SARS-CoV-2 spike protein and the ankyrin-1 protein present on the RBC membrane [14], [15], [16]. In most of the patients in this study, a rapid correction of the hemoglobin level was observed. A good response to corticosteroid therapy was noticed, except in two patients in need of additional immunosuppressive therapy.

Until now, only a few studies have presented data on the occurrence of TTP after SARS-CoV-2 infection with possible pathogenetic mechanisms. Most recently, Mancini et al. [17] have added to this data by evaluating the von Willebrand factor (VWF) a disintegrin and metalloprotease with thrombospondin 1-domain (ADAMTS-13) axis. They found that median VWF levels markedly elevated and increased with intensity of care, and there was a relative increase of intermediate and low-molecular-weight VWF multimers in severe cases. The authors concluded that an elevated VWF antigen (VWF: Ag) to ADAMTS-13 activity ratio was strongly associated with disease severity. More data are needed to clarify the possible mechanisms for the consequent onset of TTP after viral injection [18], [19]. In our study, we observed a small number of patients with TTP, all of them were treated with standard therapeutic modalities such as plasmapheresis and corticosteroids with a good response similar to TTP caused by another etiological factor.

\section{Conclusion}

Causal relationship between SARS-CoV-2 infection and these autoimmune events requires further investigations. The risk of the development of hematologic autoimmune disorders in infected patients with COVID19 should always be considered and an autoimmune etiology for cases with abnormal hematologic finding should be ruled out. This will contribute to an appropriate treatment and COVID-19 management. Therefore, the possibility of such events occurring should be taken into account, which requires constant monitoring of the patients. This will result in early physician's clinical suspicion and early measures when the manifestations of the autoimmune disorders first appear. Several reports of this condition in asymptomatic COVID-19 patients emphasize the need for COVID-19 testing in newly diagnosed patients with ITP, TTP, and AIHA amid this pandemic. 


\section{References}

1. Kadkhoda K. COVID-19: An immunopathological view. mSphere. 2020;5(2):e00344-20. https://doi.org/10.1016/j. autrev.2020.102597

PMid:32321823

2. Ehrenfeld M, Tincani A, Andreoli L, Cattalini M, Greenbaum A, Kanduc D, Alijotas-Reig J, Zinserling V, Semenova N, Amital H, Shoenfeld Y. COVID-19 and autoimmunity. Autoimmun Rev. 2020;19(8):102597.

PMid:32535093

3. Rodríguez Y, Novelli L, Rojas M, de Santis M, Acosta-Ampudia Y, Monsalve DM, et al. Autoinflammatory and autoimmune conditions at the crossroad of COVID-19. J Autoimmun. 2020;114:102506. https://doi.org/10.1016/j.jaut.2020.102506 PMid:32563547

4. Zulfiqar AA, Orenzo-Villalba N, Hassler P, Andrès E. Immune thrombocytopenic purpura in a patient with COVID-19. N Engl J Med. 2020;382(18):e43. https://doi.org/10.1056/ nejmc2010472

PMid:32294340

5. Hindilerden F, Yonal-Hindilerden I, Akar E, Kart-Yasar K. COVID-19 associated autoimmune thrombotic thrombocytopenic purpura: Report of a case. Thromb Res. 2020;195:136-8. https:// doi.org/10.1016/j.thromres.2020.07.005

PMid:32688098

6. Hindilerden F, Yonal-Hindilerden I, Akar E, Yesilbag Z, KartYasar K. Severe autoimmune hemolytic anemia in COVID19 infection, safely treated with steroids. Mediterr J Hematol Infect Dis. 2020;12(1):e2020053. https://doi.org/10.4084/ mjhid.2020.053

PMid:32670531

7. Assinger A. Platelets and infection-an emerging role of platelets in viral infection. Front Immunol. 2014;5:649. https://doi. org/10.3389/fimmu.2014.00649

PMid:25566260

8. Xu P, Zhou Q, Xu J. Mechanism of thrombocytopenia in COVID19 patients. Ann Hematol. 2020;99(6):1205-8. https://doi. org/10.1007/s00277-020-04019-0

PMid:32296910

9. Thachil J, Tang N, Gando S, Falanga A, Cattaneo M, Levi M, et al. ISTH interim guidance on recognition and management of coagulopathy in COVID-19. J Thromb Haemost. 2020;18(5):1023-6. https://doi.org/10.1111/jth.14810 PMid:32338827

10. Tang KT, Hsu BC, Chen DY. Autoimmune and rheumatic manifestations associated with COVID-19 in adults: An updated systematic review. Front Immunol. 2021;12:645013. https://doi. org/10.3389/fimmu.2021.645013

\section{PMid:33777042}

11. Pavord S, Thachil J, Hunt BJ, Murphy M, Lowe G, Laffan M, et al. Practical guidance for the management of adults with immune thrombocytopenia during the COVID-19 pandemic. Br J Haematol. 2020;189(6):1038-43. https://doi.org/10.1111/ bjh. 16775

PMid:32374026

12. Lazarian G, Quinquenel A, Bellal M, Siavellis J, Jacquy C, Re D, et al. Autoimmunehemolyticanemia associated with COVID19infection. Br J Haematol. 2020;190(1):29-31. https://doi. org/10.1111/bjh.16794

PMid:32374906

13. Hill QA, Hill A, Berentsen S. Defining autoimmune hemolytic anemia: A systematic review of the terminology used for diagnosis and treatment. Blood Adv. 2019;3(12):1897-906. https://doi.org/10.1182/bloodadvances.2019000036 PMid:31235526

14. Li Q, Cao Y, Chen L, Wu D, Yu J, Wang $\mathrm{H}$, et al. Hematological features of persons with COVID-19. Leukemia. 2020;34(8):2163-72.

PMid:32528042

15. Revuz S, Vernier N, Saadi L, Campagne J, Poussing S, Maurier F. Immune thrombocytopenic purpura in patients with COVID-19. Eur J Case Rep Intern Med. 2020;7(7):001751. https://doi.org/10.12890/2020_001751

PMid:32665935

16. da Silva RL. Viral-associated thrombotic microangiopathies. Hematol Oncol Stem Cell Ther. 2011;4(2):51-9.

PMid:21727765

17. Mancini I, Baronciani L, Artoni A, Colpani P, Biganzoli M, Cozzi G, et al. The ADAMTS13-von willebrand factor axis in COVID-19 patients. J Thromb Haemost. 2021;19(2):513-21. https://doi. org/10.1111/jth.15191 PMid:33230904

18. Zheng, XL, Vesely SK, Cataland SR, Coppo P, Geldziler B, lorio $A$, et al. ISTH guidelines for treatment of thrombotic thrombocytopenic purpura. J Thromb Haemost. 2020;18(10):2496-502. https://doi.org/10.1111/jth.15010 PMid:32914526

19. Cohen MK, Sheena L, Shafir Y, Yahalom V, Gafter-Gvili A, Spectre G. An early unexpected immune thrombotic thrombocytopenic purpura relapse associated with SARSCoV-2 infection: A case report and literature review. Acta Haematol. 2021;1-5. https://doi.org/10.1159/000514283 PMid:33895748 